\title{
Truancy: A LOOK AT DEFINITIONS IN THE US AND OTHER TERRITORIES
}

\author{
Submitted by: \\ Corresponding Author \\ Carolyn Gentle-Genitty, PhD \\ Interim Director of BSW Program \\ Assistant Professor \\ IU School of Social Work \\ 902 West New York Street, ES 4138K \\ Indianapolis, IN 46202 \\ 317-274-3965 \\ cgentleg@iupui.edu \\ Isaac Karikari, PhD Student \\ IU School of Social Work \\ 902 West New York Street, ES 4162 \\ Indianapolis, IN 46202 \\ isakarik@umail.iu.edu \\ Haiping Chen, MA, PhD student \\ IU School of Social Work \\ 902 West New York Street, ES 4162 \\ Email: haipchen@imail.iu.edu \\ Eric Wilka, MSW \\ IU School of Social Work \\ 902 West New York Street, ES 4162 \\ Indianapolis, IN 46202 \\ ewilka@umail.iu.edu \\ Jangmin Kim, PhD Student \\ IU School of Social Work \\ 902 West New York Street, ES 4162 \\ Indianapolis, IN 46202 \\ Kim795@umail.iu.edu
}

This is the author's manuscript of the article published in final edited form as:

Gentle-Genitty, C., Karikari, I., Chen, H., Wilka, E., \& Kim, J. (2015). Truancy: a look at definitions in the USA and other territories. Educational Studies, 41(1-2), 62-90.

https://doi.org/10.1080/03055698.2014.955734 


\begin{abstract}
There is no shortage of definitions for truancy. One state may house many different definitions and there are a variety of challenges arising from this fact. One of the most important to researchers, policy makers, and educators alike, is that because of the lack of uniformly and consistency, it is difficult to compile and ascertain the totality of the phenomenon. The lack of a consistent definition influences a wide range of outcomes including policy matters, financial resources and definitive responses and intervention strategies. This manuscript attempts to synthesize the literature through the examination of operational definitions of truancy in the US and in other territories. In addition to these operational definitions, expert opinions from focus groups proposed an enhanced definition of truancy. The study is qualitative and uses focus groups and synthesis of the literature to frame the work. Findings are presented. The goal is to synthesize the literature, not in its entirety, but in an attempt to combine and inform the conversation on a definition of truancy, despite initially seeming to be somewhat unachievable.
\end{abstract}

Key words: truancy, definition of truancy, focus groups on truancy, operational definitions of truancy 


\section{Truancy: A Look at Definitions in US and other Territories}

Why should we care about truancy? Truancy is a social problem around the world (Maynard, McCrea, Pigott, \& Kelly, 2012). In our view, it is riddled with multiple challenges. Most of all, there is a battle to determine whose role it is to respond to children identified as not attending school when authorities and/or their parents believe they should be attending. Unclear also is the appropriate response to such behavior. The United States has placed tremendous value on education as a way of equalizing persons from various backgrounds, classes, and cultures but the system has been constantly criticized (Levin, 1972). The major critique is that many persons, who do not succeed or fail to take advantage of the equalization opportunity provided by the American educational system, have limited participation. Subsequently, those with little education and already disadvantaged are further alienated from society (Toby, 1957).

Levin reported that "when some citizens received considerably poorer education than the norm for the society, not only will those persons suffer [and be excluded from the main stream, due to a lack of participation in the legal economy], but the larger society will suffer too” (p. 4). Sadly, students who are truant are likely to engage in delinquent behaviors and deviant practices, making it a social problem and a public health concern. School connectedness - or lack thereof - is also a factor in truancy (Barry et al., 2011; Reid, 1999, 2005), resulting in students' disengaging from formal systems, like school (Barry et al., 2011; Lawrence et al., 2011; Maynard, Salas-Wright, Vaughn \& Peters, 2012; Reimer \& Dimock, 2005). Disengaged from the formal school system, students engaged in deviant activities are educated on the streets (McDonald Brown \& Birrane, 1994) which becomes an expensive burden to tax payers ${ }^{1}$ (Bachman, Green, \& Wirtanen, 1971).

Policy makers and school personnel have relied heavily on the law and its definitions to guide their response to truancy. The categorization however, has been inconsistent, in both the US and other

\footnotetext{
${ }^{1}$ According to Mendel (2000), in reference to a study of the cost of dropping out and engaging in a life of delinquency and drugs, the total cost to the American tax payer is $\$ 470,000-\$ 750,000$ per child annually with a total lost, on average, ranging from between $\$ 1.7$ to $\$ 2.3$ million annually.
} 
territories (Maynard et al., 2012b; Reid, 2014. American academic and political scientist James Q. Wilson and economist, Glenn Loury, both suggest that this issue provides evidence of administrative deficiencies. Administrative systems have failed truant children and we must begin to make amends (Wilson \& Loury, 1987).

Chambers (2000) explains that understanding the structure of a social problem is best understood through the boundaries of the problem's goals, objectives, service delivery, and administration systems. A definition provides the goals, objectives and rules for operation. This manuscript attempts to synthesize the literature through the examination of operational definitions of truancy in the US and other territories and expert opinions to propose a common definition of truancy.

\section{Context of the Problem}

Truants do not live or operate in a vacuum. They affect and are affected by the environment around them and the outcomes outside of school (Attwood \& Croll, 2006; Epstein \& Sheldon, 2002; Reid, 2010). There is no shortage of definitions for truancy and its related factors (see: Appendix 1 - Truancy Definitions). Admittedly, definitional concerns include more than truancy and absenteeism but also interventions and strategies used to respond to students who are constantly not in attendance (Reid, 2014)

In fact, the discussions calling for common terminology or more inclusivity in the definitions of truancy are dated (Maynard, McCrea, Pigott, \& Kelly, 2012) but the attempt to synthesize and present one such inclusive definition is new. In the state of Indiana for example, there is one official legal definition of truancy, missing ten days or having more unexcused absences. However, in a research conducted with 99 principals from similarly numbered schools in Indiana, it was evident that each school also had (their) its own unofficial definition of truancy (Gentle-Genitty, 2009) see: Appendix 2- Definitions of Truancy in one Midwestern state).

This situation creates an absence of a standardized response with consequences for teachers and students alike (Reid, 2014). For instance, if the child is labelled as a truant by the school and the services and programs to respond to the social problem are limited only to the school, this will impede the ability of society to address the root cause of problems such as family, discipline, relational, financial, 
disorganization, environmental, lack of resources, supervision, and more (Chambers, 2000; GentleGenitty, 2009; Reid, 1999). A standardized truancy definition is thus the first step in facilitating better comparisons among schools and states, researchers and authors, and statistical reporting. As Maynard and colleagues (2012) report the magnitude of the problem, currently, is based on indicators used some suggesting increases, others suggesting decreases. The definition of truancy—at least one that aims to be comprehensive-must take into consideration more than the number of absences and have the potential to yield accurate accounts of the frequency of the behavior and the number of students. It must be specific and should address the problem of truancy and nonattendance.

Government and various school districts continue to make great investments in efforts to standardize truancy noting that the early intervention helps avoid or reduce the costs associated with corrective measures (Garry, 1996; Joftus \& Maddox-Dolan, 2003; Katz, 1976; McCluskey, Bynum \& Patchin, 2004). Defining truancy is the complexity of the problem and ascertaining the aspect needed for a unified, comprehensive definition is a multifaceted endeavor. Without an adequate definition of the problem and the categories or types of the problem, it is hard to assess a problem's direct impact. It is important to use an integrated theory approach (Bryson, 2004) as research urges the need to merge knowledge of the problem and the etiology of the behavior to infiltrate the problem (Catalano, Berglaund, Ryan, Lonczak, \& Hawkins, 1998). Given the variety of methods used to track chronic truancy, conducting comparison studies may be difficult, to say the least. However, synthesizing literature to tell a story of how truancy has been defined in the US and other territories can inform our next steps in such work.

\section{Purpose of Present Study}

The purpose of the study was two-fold. It was first to attempt to consolidate and or synthesize the massive amount of literature on the operational definitions of truancy. Second, it was to ground the literature with real persons engaged in the work of truancy in schools in the US and other territories through focus groups. 
The two research questions were 1) what are the operational definitions of truancy in the US and other territories, evident from the literature? 2) Can we produce a unified definition by using truancy experts in a focus group? To attempt a response to these two questions, a study design and methodology was chosen as was a convenient study sample.

\section{Method}

Two methods were used: synthesis of the literature and focus groups. To navigate the literature to find operational definitions of truancy in the US and other territories, the authors spent three years conducting a review of the literature. The database used included EBSCO Host, Academic Search Premier, SocINDEX with Full Text, Social Work Abstracts, ERIC, Education Research Complete, Educational Administration Abstracts, and Professional Development Collection. The keywords used in the search were first 'truancy', followed by ‘school non-attendance', ‘drop-outs', ‘adolescents' and 'youth'. The terms were searched individually and using “AND” as a Boolean. The last search was conducted in the fall of 2012. Two of the authors were involved in the search and selection of studies. These same two persons were involved in the data extraction process. There was no extraction form. The first person extracted any type of definition found in the literature and the second person reviewed the articles and operational definitions extracted for accuracy. A table was formed to capture the author, year of publication, and definition extracted. The screening method was used to determine the eligibility of articles which met the inclusion/exclusion criteria.

Data analysis was conducted in 2013. We understood there were multiple search terms that could have been used for this study and thus recognized the limitations with the search terms used. The decision was made to limit these terms for brevity in starting to assess the work. Although dropout can be a result of truancy, it was used because it is common for researchers and authors to speak about and define truancy as they discuss dropout. This is because truancy is a symptomatic behavioral outcome of dropout. References from each truancy article were examined and any relevant articles found, were also researched. This search was carried out until there was saturation or repetition of the same articles and authors, as determined by the authors' review. The researchers found 226 articles with the search term 
truancy. The articles found were then combed to ascertain criteria for inclusion and exclusion. Inclusion criteria: Articles included were those which were both research and conceptual and had at least some semblance of a definition of truancy for the US or other territories. By semblance we meant any statement that read as if it intended to define truancy or define characteristics of its sample. Exclusion criteria: Those conceptual and research based articles were excluded which did not have any semblance of a definition of truancy. There was not a specific search done for these criteria.

The second method that informed this work was feedback from an in-person and an online focus group conducted by the lead researcher. For the focus groups, a convenient sample was used. The primary researcher began exploring this area in 2007 and was invited to present on the topic at the International Truancy and Dropout Prevention Association (IATDP)² in 2012. To complement the work she used the one hour and a half presentation session to host a focus group on the topic of coining a common definition of truancy. Because the group was international in scope, in operation since 1911, hosting this particular focus group was ideal. Following the session, a draft definition of truancy resulted. As an additional step it was suggested that hosting of an online focus group could get the participation of the 250 active members registered on the Association's listserve to give their input on the definition. A call went out to the entire listserve asking for feedback on the definition. The result was a 28 member online focus group composed of education workers, government officials, judges, and truancy expert stakeholders with multiple years of experience in educational settings. These persons agreed to take the draft definition and voluntarily coin a comprehensive definition of truancy. After the first round of suggestions was made, the data downloaded from all emails sent to the listserves were analyzed. One of the authors sieved through the responses and identified any changes needed to the previous definition. Once completed the definition was cleaned up and amended as suggested. The third step was resending the definition again for vote and agreement. Each member who participated was invited to vote "yes” or "no" to the definition. There was

\footnotetext{
${ }^{2}$ The IATDP is a body comprising education workers, government officials and other stakeholders working jointly to address truancy and reduce student attrition. It has been in existence since 1911 (IATDP, n.d). The group, IATDP was chosen because the primary author was invited to conduct a session on defining truancy at their $102^{\text {nd }}$ conference.
} 
$100 \%$ acceptance of the definition by all 28 persons. The resulting definition was "truancy is a student's act of non-attendance evidenced by missing part or all of the school day without it being legitimately excused by school or per state law”.

\section{Results}

\section{Synthesized Literature Results}

The summary of the operational definitions of truancy in the US are presented below followed by definitions in other territories.

\section{Operational Definition of Truancy in US: Non-attendance and Absenteeism}

For the operational definition of truancy, we used only the results from the eight databases noted in the methods section with search term “truancy.” The result was 226 articles. Of the 226, 137 were automatically excluded as the abstracts did not discuss truancy in detail and offered no semblance of a definition of truancy. Of the remaining articles, 89 were read but another 26 were excluded for lack of relevancy or despite key words listed as truancy the key word tags did not have anything to do with Truancy. Of 63 articles on truancy extracted and reviewed in an attempt to synthesize available literature, the findings stressed the point of non-attendance and absenteeism when defining or explaining truancy (i.e. Claes, Hooghe \& Reeskens (2009); Darmody, Smyth \& McCoy (2008); Dube \& Orpinas (2009); Epstein \& Sheldon (2002); Fantuzzo, Grim \& Hazan, 2005; Gastic, 2008; Gleeson (1992); Goldberg (1999); Kearney (2008); Lawrence, Lawther, Jennison \& Hightower (2011); Lehr, Sinclair \& Christenson (2004); McIntyre-Bhatty (2008); Newsome et al., (2008); Pritchard \& Williams (2001); Reid (2003b); Reid (2004); Rhodes, Thomas, Lemieux, Cain \& Guin (2010); Ventura \& Miller (2005). These authors used the word absent, absenteeism, or non-attendance in their definitions or explanations.

The review of the literature, using the database above, suggests that there already existed one comprehensive definition. This definition used currently by various truancy reduction programs was coined by the Office of Juvenile Justice and Delinquency Prevention (OJJDP). It defined truancy as a person "who misses 20\% or more of school days within a six week period” (1996, p. 1). This definition 
was not found to be used in territories other than the US.

Other singular definitions include Wilson, Malcolm, Edward and Davidson (2008) who identified truancy as an absence, of which pupils themselves indicated would be unacceptable to teachers. Another definition defined truancy as students distancing themselves from school and issues related to rates of daily student attendance (Epstein \& Sheldon, 2002). Hendricks, Sale, Evans, McKinley and DeLozier (2010) looked at truancy in terms of the percentage of hours students spent in school per semester. Other organizations like the Boston Urban Youth Foundation in the United States ${ }^{3}$ define truancy as lateness to class and excused absences for long periods - i.e., not showing up to class for more than three days (Rodríguez \& Conchas, 2009). In contrast to how the Boston Urban Youth Foundation determined truancy and habitual lateness, an Early Truancy Intervention (ETI) study conducted in a southern school district in the United States, classified students as truants if they were absent for 15 or more times (Lawrence et al., 2011). The instances and examples mentioned above are illustrations from the literature that there is no single or common standard operational definition for determining what constitutes truancy or classification of truancy (Attwood \& Croll, 2006).

Berg (1997) presents another dimension of school absenteeism known or referred to as school refusal. The criteria for determining school refusal are when a child:

(1) Seeks the comfort and security of home, preferring to remain close to parental figures, especially during school hours;

(2) Displays evidence of emotional upset when faced with the prospect of having to attend school, although this may only take the form of unexplained physical symptoms;

(3) Manifests no severe antisocial tendencies, apart from possible aggressiveness, when attempts are made, to force school attendance; and (4) does not attempt to conceal the problem from parents (Berg, 1997, p. 90).

\footnotetext{
3 The Boston Urban Youth Foundation is a community-based organization with a focus on helping Black and Hispanic youth toward a more secure academic future (Rodríguez \& Conchas, 2009).
} 
Unlike typical truancy, school refusal cannot be said to be more peculiar to people of any one particular social class or status (Reid, 2014). Additionally, it does not have any direct relationship with a student's capacity or ability for learning. It is however more likely to occur as children grow and move from the primary or elementary level of school to higher levels (Berg, 1997). According to Kearney (2006, 2007), school refusal represents the overarching concept of school avoiding behaviors which include truancy. Common themes from the literature also indicate that, in the US, the definitions tended to be influenced by the school's view of the problem as unacceptable behavior compared to students' perspectives as distancing from the school environment (Reid, 2014) (See Table 1). This discovery may suggest to us that as we aim to coin a unified definition in the long-term, beyond the scope of this manuscript, we may have to speak to the view of the school and the view of the student. Truancy is part of that collective. It is necessary to note that school absence and truancy are not entirely the same. In essence not every unexcused absence should be labeled truancy (Darmody et al., 2008; Gleeson, 1992). Some school policies (such as those pertaining to holidays) may set the stage or result in instances of unexcused absences (Darmody et al., 2008).

Table 1 - Studies in the US

\begin{tabular}{|c|c|c|}
\hline Category & Author(s) \& Year & Definition(s) and Conception(s) of Truancy \\
\hline \multirow[t]{3}{*}{$\begin{array}{l}\text { School Perspectives: } \\
\text { Unacceptable } \\
\text { behavior }\end{array}$} & $\begin{array}{l}\text { Barry, Chaney \& Chaney } \\
\text { (2011); Henry (2007; 2010); } \\
\text { McNeal Jr. (1999) }\end{array}$ & $\begin{array}{l}\text { - } \quad \text { Skipping or cutting school/classes. } \\
\text { - Intentional absence from school; intentionally leaving school early, } \\
\text { or intentionally missing classes. } \\
\text { - School non-attendance }\end{array}$ \\
\hline & $\begin{array}{l}\text { DeSocio, VanCura, Nelson, } \\
\text { Hewitt, Kitzman \& Cole } \\
\text { (2007); Fantuzzo, Grim, \& } \\
\text { Hazan (2005); Lehr, Sinclair } \\
\text { \& Christenson (2004); } \\
\text { McCray (2006)Newsome et } \\
\text { al (2008); Rhodes, Thomas, } \\
\text { Lemieux, Cain \& Guin } \\
\text { (2010); Sinha (2007) }\end{array}$ & $\begin{array}{ll}\text { - } & \text { Unexcused absences from school or classes. } \\
\text { - } & \text { Unexcused absences from school; chronic unexcused } \\
\text { - } & \text { School absenteeism } \\
\text { - } & \text { Staying away without permission } \\
\text { - } & \text { Chroncused absence from school; absenteeism } \\
\text { - } & \text { specific classes } \\
& \text { Unexcused absence of students from school }\end{array}$ \\
\hline & $\begin{array}{l}\text { Gastic (2008); Henry, } \\
\text { Thornberry \& Huizinga } \\
\text { (2009); Henry \& Thornberry } \\
\text { (2010); Rhodes \& Reiss } \\
\text { (1969); Ventura \& Miller } \\
\text { (2005); Zhang, Katsiyannis, } \\
\text { Barrett, \& Wilson (2007; } \\
\text { 2010) }\end{array}$ & $\begin{array}{l}\text { - Unexcused absences from school for the entire day or a particular } \\
\text { - } \quad \text { The study also discussed thoughts of intentionally missing school as } \\
\text { playing a role in truancy. } \\
\text { - } \quad \text { Skipping school without a valid excuse } \\
\text { - } \quad \text { Physical withdrawal from school and labeled it as active avoidance } \\
\text { - } \quad \text { Habitual engagement in unexcused absences from school. }\end{array}$ \\
\hline
\end{tabular}




\begin{tabular}{|c|c|c|}
\hline & Dube \& Orpinas (2009). & Absent without knowledge of parents; excessive absenteeism. \\
\hline & Kearney $(2006,2007,2008)$ & $\begin{array}{l}\text { - Part of a collective of school avoiding behaviors considered to be } \\
\text { problematic. Manifestations of such behavior include anxiety while } \\
\text { in school, skipping some classes and not attending school } \\
\text { - School refusal behavior is the overarching concept of such behavior. } \\
\text { - Illegal, unexcused absence from school; absenteeism without } \\
\text { parents knowledge; excessive absenteeism marked by child anxiety } \\
\text { as well absence from school correlated with deviant behavior and } \\
\text { academic problems, family related problems and socio-economic } \\
\text { disadvantage. }\end{array}$ \\
\hline \multirow[t]{2}{*}{$\begin{array}{l}\text { Student Perspective: } \\
\text { Distance from } \\
\text { School }\end{array}$} & Epstein \& Sheldon (2002). & $\begin{array}{l}\text { - Focuses on students distancing themselves from school; and issues } \\
\text { related to rates of daily student attendance. }\end{array}$ \\
\hline & $\begin{array}{l}\text { Fallis \& Opotow (2003); } \\
\text { Hallfors et al. (2002); Walls } \\
\text { (2003) }\end{array}$ & $\begin{array}{l}\text { - } \quad \text { Class cutting. } \\
\text { - Presents it as a deliberate act in an effort to avoid certain people or } \\
\text { courses. } \\
\text { - Makes an important observation that “cutting is the slow-motion } \\
\text { process of dropping out made class-by-class and day-by-day in } \\
\text { students' daily lives” (p. 104). } \\
\text { - Skipping school; cutting classes. } \\
\text { - Truancy is an indicator of low school attachment } \\
\end{array}$ \\
\hline
\end{tabular}

\section{Different Definitions of Truancy in Other Territories}

Truancy is a global phenomenon. School non-attendance is a subject that has attracted a lot of interest both locally and internationally. It is a subject on which much research continues to be conducted; as well as, a phenomenon that is very complex. Part of this complexity becomes evident in the lack of a common universal definition (Claes et al., 2009; Lawrence et al., 2011). Yet, it is widely acknowledged as a problem (Mounteney, Haugland \& Skutle, 2010; Pathammavong et al., 2011). In fact, what has created a lot of challenges in researching the topic and problem of truancy is the usage of many informal terminologies to classify, categorize, report, and respond to truancy. With no dataset being the same, any comparison study on truancy is suspect and automatically flawed. Attempts to curb the problem have been futile. Failure to do so is an injustice to students everywhere. The operational definitions found for truancy in other territories are only a small indication that the problem is not US based but world-wide.

Reid (2005, 2010, and 2014) has multiple definitions of truancy, types, and categories in describing the phenomena of truancy and labels absences as unacceptable by teachers and local education authorities. Similarly, Lawrence and colleagues (2011) identified some informal terms and slangs for truancy in six countries across the world. For example, in Australia, it may be commonly 
referred to as either wagging or bludging; in South Africa, bunking or jippo; in Ireland it and UK is referred to as mitching; in India, skipping; in England as twagging, and in the United States as either sloughing, ditching, or hooky. It must also be noted that other slang terms may exist, yet they may not have been documented. Lack of documentation of terms used is a growing concern in other territories.

The most comprehensive study found was by Claes and colleagues (2009). They conducted a 28 nation comparative study. Claes et al. (2009) presented truancy as absence without authorization. Though these researchers claim a common definition was used in the study, they also referenced countries in their study such as Great Britain that has no clear statutory definition of truancy (Davies and Lee, 2006).

Practices such as going on holidays or shopping trips and visiting relatives when school is in session may count as truancy. Consequentially, Claes et al. (2009) note that definitions of truancy are contextual and may vary from one setting to another as determined by the existing rules in a country or state. Mounteney et al. (2010) equally point out the impact of local and international laws in determining truancy; yet their study of truancy in Norway revealed the phenomenon is generally similar to what has been presented in places such as the United States and Britain. Pathammavong and colleagues (2011) in their Canada study presented similar notions. For example, Mounteney and colleagues (2010) and Pathammavong and colleagues (2011) mentioned skipping class as indicative of truancy.

In Cambodia, truancy can generally be referred to as unexcused absences (Goldberg, 1999). Furthermore, absences are considered to be unexcused if there is no written note from a parent or teacher or some official document from a doctor explaining a student’s absence (Goldberg, 1999). See Table 2 for operational definition in other territories.

Table 2 - Some Operational Definitions in Other Territories

\begin{tabular}{|c|l|l|l|}
\hline Categories & Author(s) \& Year & Country & Definition(s) and Conception(s) of Truancy \\
\hline $\begin{array}{c}\text { Comparison } \\
\text { Study }\end{array}$ & $\begin{array}{l}\text { Claes, Hooghe \& } \\
\text { Reeskens (2009). }\end{array}$ & $\begin{array}{l}\text { 28 nation comparative } \\
\text { study: Australia, } \\
\text { Belgium, Bulgaria, } \\
\text { Chile, Colombia, } \\
\text { Cyprus, Czech Republic, } \\
\text { Denmark, Estonia, } \\
\text { Finland, Germany, }\end{array}$ & $\begin{array}{l}\text { Any unexcused or undocumented absence from } \\
\text { school. Definitions are contextual and may be } \\
\text { determined by the existing rules in a country or } \\
\text { state. }\end{array}$ \\
& & $\begin{array}{l}\text { Forms of truancy: encompasses pupils that arrive } \\
\text { late in a systematic manner and those who do not } \\
\text { arrive at school at all. }\end{array}$ \\
\hline
\end{tabular}




\begin{tabular}{|c|c|c|c|}
\hline & & $\begin{array}{l}\text { Greece, Hong Kong, } \\
\text { Hungary, Italy, Latvia, } \\
\text { Lithuania, Norway, } \\
\text { Poland, Portugal, } \\
\text { Romania, Russia, Slovak } \\
\text { Republic, Slovenia, } \\
\text { Sweden, Switzerland, } \\
\text { United Kingdom, United } \\
\text { States }\end{array}$ & \\
\hline $\begin{array}{l}\text { One Nation } \\
\text { Study }\end{array}$ & $\begin{array}{l}\text { Darmody, Smyth \& } \\
\text { McCoy (2008). }\end{array}$ & Republic of Ireland & $\begin{array}{l}\text { Unauthorized and illegitimate absences; } \\
\text { intentional absence from specific classes; chronic } \\
\text { absenteeism. } \\
\text { School absence and truancy are not entirely the } \\
\text { same -not every unexcused absence should be } \\
\text { labeled truancy. Some school policies (such as } \\
\text { those pertaining to holidays) may set the stage or } \\
\text { result in instances of unexcused absences. }\end{array}$ \\
\hline & $\begin{array}{l}\text { Attwood \& Croll } \\
\text { (2006) Davies \& Lee } \\
\text { (2006); Gleeson } \\
\text { (1992); McIntyre- } \\
\text { Bhatty (2008); Reid } \\
\text { (2003a, 2003b, 2004, } \\
\text { 2005, 2006, 2008, } \\
\text { 2010); Southwell } \\
\text { (2006);Wardhaugh } \\
\text { (1990); Wilson, } \\
\text { Malcome, Edward, \& } \\
\text { Davidson (2008) }\end{array}$ & UK & 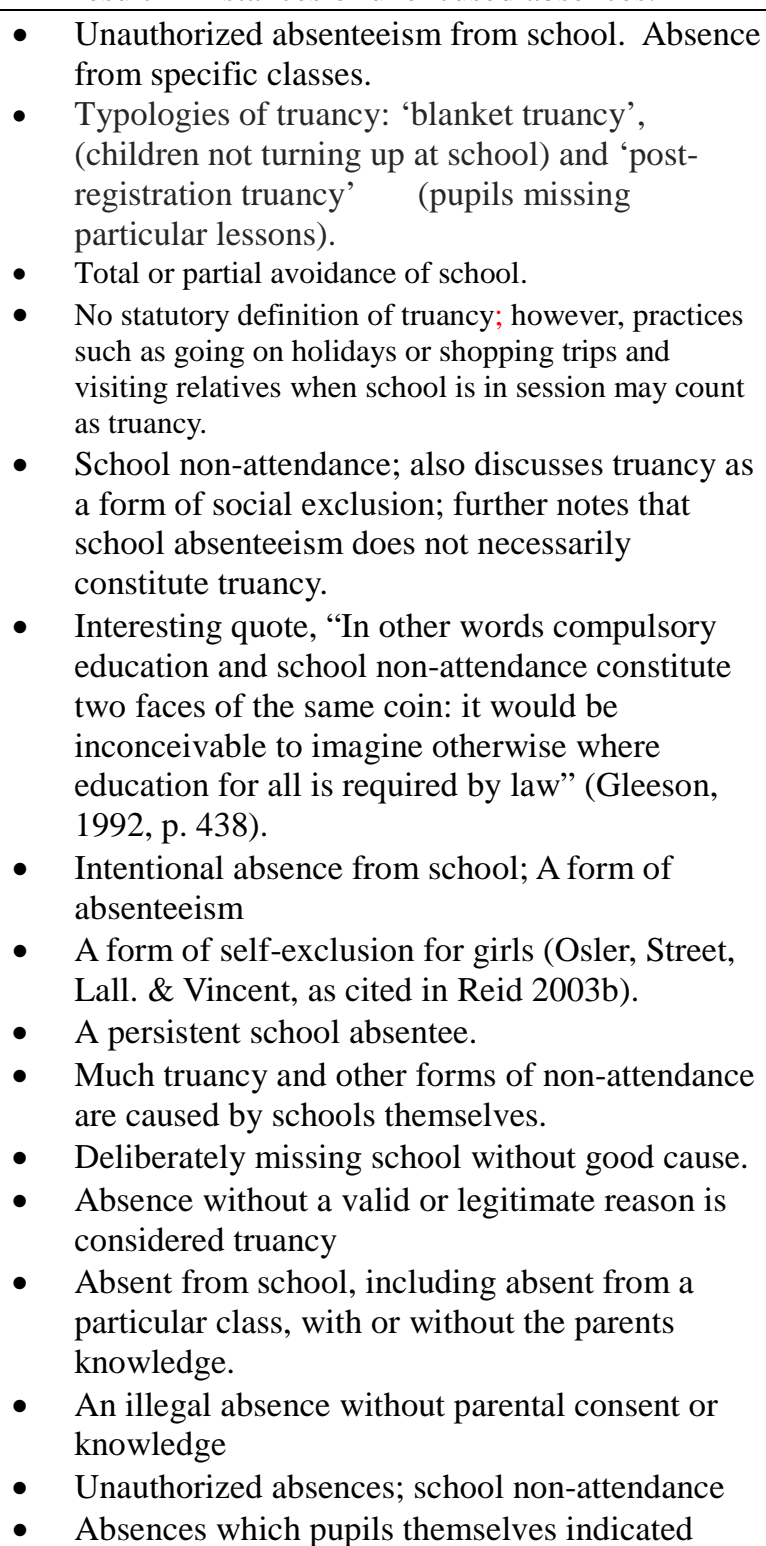 \\
\hline
\end{tabular}




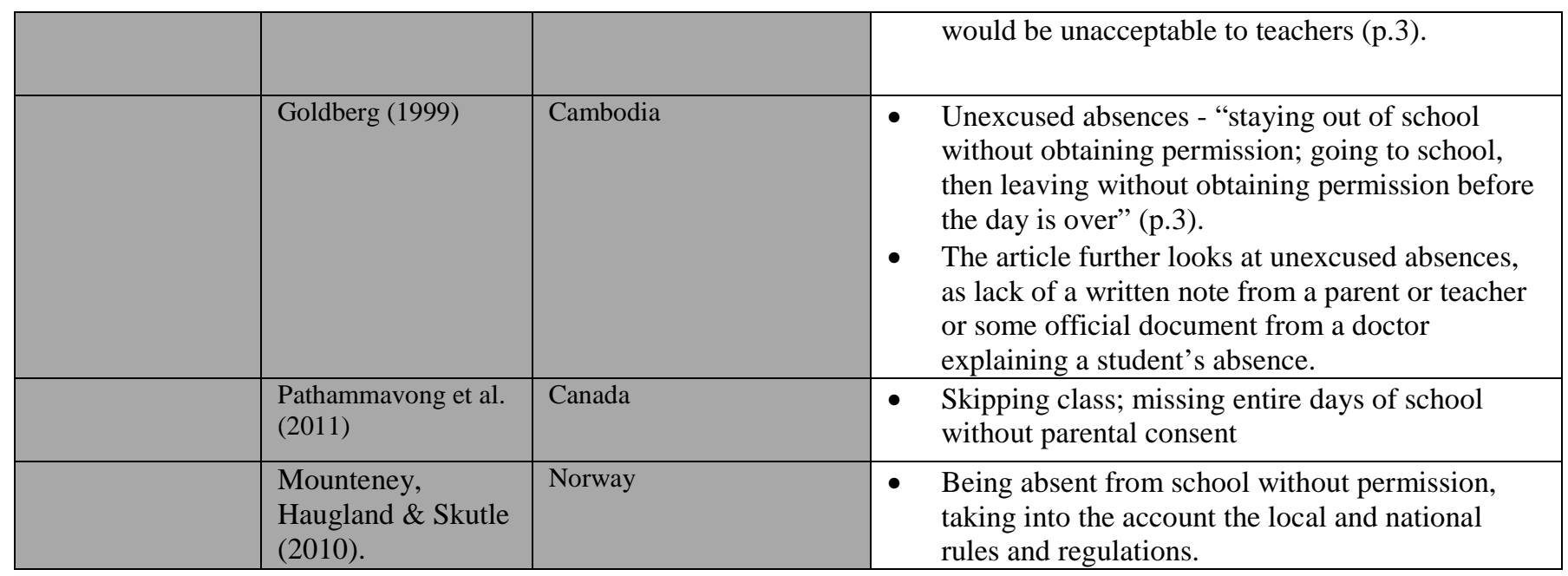

\section{Sub-categories of Truancy in the US and other territories}

Beyond the operational definitions of truancy several scholars called for distinctions among student absences and non-attendance, noting that absences could be either authorized or unauthorized i.e., unexcused absences (Attwood \& Croll, 2006; Hartnett, 2007, O’Keefe \& Stoll, 1994). Maynard and colleagues (2012b) refer to the need of such distinctions in interventions too. For instance, Walls (2003) presents two types, those who cut or miss class, and those who miss full days. Claes, Hooghe and Reeskens (2009) likewise point out typologies of truancy framed differently from O’Keefe and Stoll’s (1994). According to Claes et al. (2009), truanting students may be categorized as those "pupils that arrive late in a systematic manner” and those who do not come at all (p. 124). Hendricks et al. (2010) identified three levels of truancy - severe (students with less than $79 \%$ of hours present during the baseline semester), moderate (79\% -87\% hours present), and mild (88\% - 90\% hours present). Reid’s 1985 work also offers four categories of truancy which captures different patterns and characteristics of non-attendance. In what he termed "categories of persistent absence”, the four categories were: traditional or typical absentee, institutional absentee, psychological absentee and the generic absentee (p. 48). The traditional or typical absentees are usually from unsupportive backgrounds with unfavorable and troubling social circumstances. They are likely to have issues related to low selfconcept such as low self-esteem and feelings of inadequacy. The institutional absentee, unlike the 
traditional or typical absentee, may not have any self-concept related problems. Their backgrounds may play into the reason for their truancy but institutional absentees generally miss school for educational reasons. They may avoid particular lessons or classes or school days. In some cases, they may miss class periods but still remain on the school premises. The psychological absentee avoids school for psychologically-based reasons or a general fear of school. This may be as a result of factors such as physical disabilities that put them at a disadvantage as well as encounters with bullies. The generic absentee is one who misses school for any of the aforementioned reasons. These categories by Reid (1985) reflect some of the earliest attempts at delineating the peculiar characteristics of truants and the nature of student absence. They are, however, broad.

Other scholars have mentioned forms of persistent absence or truancy which may previously have been subsumed under Reid's (1985) categories. O’Keefe and Stoll (1994) conducted a study investigating the causes and the scale truancy problems among pupils in years 10 and 11 , covering 150 schools and a total number of 37,683 pupils. In their study, truancy was divided into two broad forms namely postregistration truancy (PRT) and blanket truancy (BT). They defined BT as "unjustified absence from school of pupils who have not registered in school” (O’Keefe \& Stoll, 1994, p.29). PRT basically entails absence from lessons after registration. O’Keefe and Stoll (1994), further dichotomized PRT into offsite and onsite truancy to differentiate between cases where students leave the school premises and cases where they still remain in school even though they do not go to class. Looking at the description for PRT, and its two forms, the point can be made that it was previously subsumed under Reid's (1985) category of the institutional absentee. Reid $(2005,2010)$ further elaborates on PRT by stating that a student may still be on the school premises and yet not attends classes and when such students do attend class, whether coerced or compelled, they may be physically present, but mentally absent, thereby furthering the achievement gap in education.

In explaining the patterns and trends of truancy, some scholars mention the intentionality behind students’ avoidance of particular lessons and leaving school early. In other words, students deliberately skip school or cut classes (Barry, Chaney \& Chaney, 2011; Darmody, Smyth \& McCoy, 2008; DeSocio et 
al., 2007; Fallis \& Opotow, 2003; Hallfors et al., 2002; Henry, 2007, 2010; Kearney, 2006, 2007; Reid, 2003; Spencer, 2009). Others mention persistent absence from school (Darmody et al., 2008; Dube \& Orpinas, 2009; McIntyre-Bhatty, 2008; Rhodes, Thomas, Lemieux, Cain \& Guin, 2010), which reveals why truancy and chronic absenteeism are often used interchangeably (Lawrence, Lawther, Jennison \& Hightower, 2011; Lehr et al., 2004; McCray, 2006).

Also, what may sometimes be noted as other forms of truancy and absenteeism such as specific lesson absence, parentally condoned absence, near truancy (psychological absence), school refusal, and school phobia (Reid 1999, 2005, 2010, 2014) are in some cases reiterations or the further breaking down of previously noted forms. The motive for skipping school or cutting classes may sometimes be a deliberate act not just to avoid certain courses or lessons but certain people as well (Fallis \& Opotow, 2003), such as a particular teacher or a classmate. Beyond normal school hours and conventional academic activities, students can also be considered truants for unexcused absences or deliberately avoiding particular extracurricular activities (Gastic, 2008) or failure to comply with policy. In fact in some school districts in the United States (such as the North Thurston, Mead, Seattle and Spokane School Districts in the state of Washington), the attendance policy requires students to submit a note signed by a parent or guardian confirming their absence from school. Students 18 years of age are exempt from this requirement (Hartnett, 2007). Hartnett (2007) reveals how elaborate some of the policies regarding attendance can be; a case in point is that of the state of Washington. In situations of repeated illness, a note may be required from a doctor. When absenteeism continues for 20 days in succession, a student may lose his or her place in school, which means the school will cut them off. Hartnett (2007) also identifies some of the limitations of the policy. For instance, the policy does not give consideration to students whose absence may be necessitated by a need to help at home. Again, consideration is not given to those whose absence may be occasioned by their parents’ inability to take them to school. Congruously, in the state of Wisconsin, accumulating five or more illegal absences in a semester is considered habitual truancy (Henry, Thornberry \& Huizinga, 2009). Illegal absences thus refer to 
absences that are not endorsed by the school or a student's parents. Some of these concerns also occur in other territories.

\section{Results from the Online Focus Group and In-person sessions}

To ground the synthesis of the literature it was important to speak with persons who were currently working in the field of truancy. Two focus groups were conducted. A summary of the focus group concerns was generated from an in-person and online focus group.

In general, truancy was a concern for all persons in the focus groups. More specifically, in the review of the transcripts from the online focus group and notes from the in-person focus group to generate a common definition, there were four concerns. These included the need for a uniform definition as there are various definitions from state to state, country to country. Second, they noted that most definitions and laws lacked properties to respond to children who do not live with their parents or who were not enrolled at all. The third concern was the discussion that most definitions did not differentiate between excused and excusable absences. Lastly they noted that definitions currently do not attempt to respond to the missed opportunities for learning. Despite some observations highlighted below, both groups lamented on concerns for the need of a definition but that it was complex. However after the hour and a half long discussion in the face to face group they determined that the definition needed to be broad, include who is responsible, and the number of days. In addition some members and one in particular wanted to use the word student instead of child. She writes "Works for me. I would just replace child with student so it fits all grade levels. I know how folks in upper grades don't like being thought of as children.”

The participants noted that no definition was conclusive but that it would be a start to allow for persons around the world to have a common definition on which to hang their hat and inform their special context. They lauded the idea that some places viewed truancy as illegal when in fact the child, often truant, is in fact underage and under the care of his or her parents. Concerns like these, they stated, should be responded to using policy and revised legislation. In attacking legislation the age of the truant child 
must also be re-established so that a person will know who is included and not included when they mention a truant child.

In general, the definitions shared were very different and many thought other aspects should be included in their own respective state definitions. One respondent suggested that it goes beyond just the truancy definition but the words excused and unexcused should be included. "Here's the problem I have with using the word "excused" or "excusable" in the definition of truancy: parents will always argue that any time they produce a note with a reason for their student's absence it is/should be excused. We must, therefore, further define what we mean by "excused" or "excusable" in order to more clearly and comprehensively define truancy” (Person 5). Because of it being a status offense and vary by state, person 8, a local District Attorney wrote "for now, in terms of excusable and inexcusable, we need to look towards our own State laws to guide us on that. Maybe that segment should be included [in our uniform definition is] legitimately excused per State law, city ordinance.” In addition, person 7 went on to say "I would also add that the word 'truant' itself tends to have a connotation referring to kids that are 'delinquent.' In our schools, officials have a hard time with calling elementary age students ‘truants’. This is why we went toward nonattendance.”

Another concern was that of having a uniform definition. Many spoke out about it being important and two respondents shared that "it would be remarkable if we could come to a consensus as an organization. We all agree that the definition of truancy is very important” (Person 1 and 4). Spotlighting a very different concern that results from this discussion was what person 3 wrote "there also is the issue of those students that never enroll. Technically they aren't absent because of non-enrollment”. However, the concern of not having a dropout age was also a concern for some (Persons 1, 2, \& 4).

Lastly, another concern was that even if a uniform definition could not be found, there should be some agreement on the compulsory age for education and the persons who hold responsibility. In regard to the concern of responsibility, Person 2 remarked that "what I don't understand in our district is that you can 'drop out' without parental permission. But then we have kids who want to come back to school who 
let's say parents can't get off work, or even worse, don't care, the student can't re-enroll without a parent.” The concept of having a uniform definition is touted as being important by several respondents. For instance, Person 4 said "as an international organization, we may need to ensure that the age is the same from state to state." Person 8 emphasized school age as being important in her definition, "truancy is the act of a school aged student being ...” In addition, person 5 added that the “Texas statutes actually address students who are of compulsory attendance age but not enrolled in school and who are known to live within district boundaries. The problem with those students is that we rarely become aware of them unless a neighbor or concerned citizen reports them for being outside during the school day. In our district, our attendance administrators make a home visit and are generally told the student is being home schooled. In Texas, we then have no further educational jurisdiction over the student.” These are the concerns that do not clearly identify responsibility and response. On average, the participants included persons who had education levels of no less than a bachelor's degree and no more than a doctoral degree. They ranged from judges, social workers, truancy experts, researchers, pupil attendance officers, supervisors, executive directors, teachers, community outreach coordinators, and teen court coordinators.

\section{Discussion}

\section{From Literature}

There is a need for a common definition. Challenges in comparative assessments have been flawed with the absence of a consistently used definition of truancy. Maynard, McCrea, Pigott, \& Kelly, (2012) in their systemic study of interventions found that the numerous gaps and deficiencies in the literature must change and doing the same thing expecting different results is simply not enough. Clear in this review is that much of the same continues and we were far from having a common definition. The OJJDP definition came closest but lacked some aspects. For instance, though this definition could potentially have students missing much more than 10 days over a school year, it can encourage principals to have an earlier identification and intervention point with truants. Thus, we need to incorporate some way of not just collecting and storing data on absences, but also various categories and type-sets, like those presented herein, with no intention of purposely labeling students, but to effectively respond to the 
variations in truancy. As the definition is revised and standardized, the tracking methods would be improved. Today many schools use attendance registers held by teachers; however, this option of tracking is often flawed, despite its convenience and cost-effectiveness. Students often leave the school system and are dropped from registers with little to no verification of their whereabouts (Montecel, Cortez, \& Cortez, 2004). For instance, the review of the literature noted that there can be lesson-absence, post-registration and parental-condoned truancy types (Reid, 1999, 2005, 2014). The Office of Juvenile Justice and Delinquency Prevention (OJJDP) found that there were four correlates of truancy: the family situation, school performance, economic indicators, and individual student variables (Baker, Sigmon \& Nugent, 2001). ). In addition, awareness of various categories of truants, such as traditional, psychological, institutional, recreational, and life-style can help us develop program-specific responses for truants (Bonikowske, 1987; Reid, 1999). This latter portion also presents a concern about the many informal ways of referring and discussing truancy thereby impacting the study of the area comprehensively. In addition, it must be noted that school non-attendance and truancy may further be compounded by the immigration status of families, and adherence to religious conventions among other things. These are factors that may require further exploration. We [researchers and authors of this article] agree there are some legal aspects but it has now spanned the scope of a societal problem and not just one for the truant officers, case workers, and the courts.

In some cases there were differences between absences and non-attendance but very little on the differentiation between excused and excusable absences. This seemed to vary when we categorized by student perspectives and the school's view of truancy. This was cloudy even more when the many informal terminologies were infused. As a result it would be fair to say that because the search terms were limited to the formal terminology a lot of data were not included because informal terms were not known and hence absent from the search. More work and collaborative approaches are needed to respond to defining and tracking truancy so that our report is effective in scope.

\section{From focus group}


The organization used for the study, IATDP, provided a platform to reach persons around the world. However, there were immediate limitations. First and foremost, not many international persons were present at the conference that year. Secondly, most participants spoke from their vantage point, considering only their units. This further excluded international contexts. The most notable concern was that this was the first forum of its kind known to the authors. As a result, many of the participants valued participating and sharing their viewpoints but also had other concerns they wanted to address. Thus the forum was unable to respond to all the concerns and forum needs. For instance, someone posted that "I am so excited to see and know that the Open Forum dialogue continues. The definition of truancy is very important. However, I would also like a national "drop out age". As an International organization, we may need to ensure that the age is the same from state to state. Please share your thoughts!” As this was out of the scope of the work, the concern was not addressed. Another respondent shared "My thoughts are; I agree it would be remarkable if we could come to a consensus as an organization. We all agree that the definition of truancy is very important. I think a national "Drop out age” would be tremendous! I think we may want to remember the reason for trying not being so specific is because of the various definitions from state to state. Thanks so much for all of your help to get us were we want to be.”

The final definition the group crafted was “Truancy is a student's act of non-attendance evidenced by missing part or all of the school day without it being legitimately excused by school or per state law.” Consequentially, given the complexity of truancy as a phenomenon, some aspects were absent from this definition. It was reworked by the authors to read...Truancy is a non-home school student's act of non-attendance evidenced by missing part or all of the school day without it being authorized by medical practitioner or sanctioned by parent(s) and/or legitimately excused by school or per state law. The aspects emphasized were to characterize that it does not include children who were home-schooled, that it was the act and not the person, the differentiation between part and whole days, making sure to remove excused and excusable absences such as those characterized by a doctor's note or those with parent or school permission and state law. Of course this is the first iteration and needs much refining using a collaborative approach. 


\section{Conclusion}

The authors of this article know there are flaws in every definition and by no means are we requesting that this be the specific definition endorsed. As researchers, however, someone or some entity needs to take charge rather quickly to coin a definition of truancy. The outcome can be the development and use of consistent benchmarks for systematic measurement and comparison nationally. Yes, this is only but one attempt to find a way to effectively measure and track truancy and there are other forms of school refusals. Berg (1997) points out that school absenteeism known or referred to as school refusal is more likely to occur as children grow and move from the primary or elementary level of school to higher levels, and school refusal too is likely to occur after some prolonged absence from school as a result of illness or holidays. However, school refusal in general is not new and policy makers, educators and administrators, social workers, and researchers will continue to have ways of capturing what it involves and by such extension difficulty defining it...

The effort was made to craft a common uniform definition for truancy; one that seeks to be comprehensive in scope and simple in nature. It was hoped that this uniform definition or something similar, could be adopted by schools and data sources to enable comparisons and data collection across states and school systems. Only when such is in place, will policy makers, educators and administrators, social workers and researchers be better able to address and curb this global phenomenon. It is a social plight that is personally and socially counterproductive and debilitating to the economy and our society. The work herein aimed to respond to an important aspect of truancy and to synthesize the literature and find consensus on a definition of truancy. We agree that continued discussion and debate about truancy and how truancy is defined is important. 
References

Attwood, G., \& Croll, P. (2006). Truancy in secondary school pupils: prevalence, trajectories and pupil perspectives. Research Papers in Education, 21(4), 467-484.

Baker, M.L., Sigmon, J.N., \& Nugent, M.E. (2001). Truancy reduction: Keeping students in school. Washington, DC: Office of Juvenile Justice and Delinquency Prevention.

Bachman, J.G., Green, S., \& Wirtanen, I.D. (1971). Dropping out - problem or symptom. Youth in transition (Vol. III), Ann Arbor, Mich: Institute for Social Research, University of Michigan.

Barry, A. E., Chaney, B., \& Chaney, J. (2011). The impact of truant and alcohol-related behavior on educational aspirations: A study of us high school seniors. Journal of School Health, 81(8), 485-492.

Berg, I. (1997). School refusal and truancy. Archives of Disease in Childhood, 76(2), 90-91.

Bonikowske, D. (1987). Truancy: A prelude to dropping out. Bloomington, IN: National Education Service.

Bryson, J.M. (2004). Strategic planning for public and non-profit organizations: Guide to strengthening and sustaining organizational achievement, ( $3^{\text {rd }}$ Ed). San Francisco, CA: Jossey-Bass

Catalano, R.F., Berglaund, H.L., Ryan, J.A.M., Lonczak, H.S., \& Hawkins, J.D. (1998). Positive youth development in the United States: Research findings on evaluations of positive youth development programs. Social Development Research Group: University of Washington. Retrieved March 16, 2006 from: http://aspe.hhs.gov/hsp/PositiveYouthDev99/index.htm.

Chambers, D.E. (2000). Social policy and social programs: A method for the practical public policy analyst ( $3^{\text {rd }}$ Ed.). Boston: Allyn \& Bacon.

Claes, E., Hooghe, M., \& Reeskens, T. (2009). Truancy as a contextual and school-related problem: A comparative multilevel analysis of country and school characteristics on civic 
knowledge among 14 year olds. Educational Studies (03055698), 35(2), 123-142.

Darmody, M., Smyth, E., \& McCoy, S. (2008). Acting up or opting out? Truancy in Irish secondary schools. Educational Review, 60(4), 359-373.

Davies, J., \& Lee, J. (2006). To attend or not to attend? Why some students chose school and others reject it. Support for Learning, 21(4), 204-209.

DeSocio, J., VanCura, M., Nelson, L. A., Hewitt, G., Kitzman, H., \& Cole, R. (2007). Engaging truant adolescents: Results from a multifaceted intervention pilot. Preventing School Failure, 51(3), 3-9.

Dube, S. R., \& Orpinas, P. (2009). Understanding excessive school absenteeism as school refusal behavior. Children \& Schools, 31(2), 87-95.

Epstein, J. L., \& Sheldon, S. B. (2002). Present and accounted for: Improving student attendance through family and community involvement. The Journal of Educational Research, 95(5), 308-318.

Fallis, R., \& Opotow, S. (2003). Are students failing school or are schools failing students? Class cutting in high school. Journal of Social Issues, 59(1), 103-119.

Fantuzzo, J., Grim, S., \& Hazan, H. (2005). Project start: An evaluation of a community-wide schoolbased intervention to reduce truancy. Psychology in the Schools, 42(6), 657-667.

Fine, M. (1991). Framing dropouts: Notes on the politics of an urban public high school. Albany, NY: State University of New York Press.

Garry, E.M. (1996). Truancy: First step to a lifetime of problems. Washington, DC: US Department of Justice: Office of Juvenile Justice and Delinquency Prevention.

Gastic, B. (2008). School truancy and the disciplinary problems of bullying victims. Educational Review, 60(4), 391-404.

Gentle-Genitty, C. (August 2009). Tracking more than absences: Impact of schools’ social bonding on chronic truancy. Saarbrücken, Germany: Lambert Academic Publishing.

Gleeson, D. (1992). School attendance and truancy: a socio-historical account. Sociological Review, 40(3), 437-490.

Goldberg, M. E. (1999). Truancy and dropout among Cambodian students: Results from a 
comprehensive high school. Social Work in Education, 21(1), 49-63.

Hallfors, D., Vevea, J. L., Iritani, B., Cho, H., Khatapoush, S., \& Saxe, L. (2002). Truancy, grade point average, and sexual activity: A meta-analysis of risk indicators for youth substance use. Journal of School Health, 72(5), 205-11.

Hartnett, S. (2007). Does peer group identity influence absenteeism in high school students? High School Journal, 91(2), 35-44.

Hendricks, M. A., Sale, E. W., Evans, C. J., McKinley, L., \& DeLozier Carter, S. (2010). Evaluation of a truancy court intervention in four middle schools. Psychology in the Schools, 47(2), 173-183.

Henry, K. L. (2007). Who's skipping school: Characteristics of truants in 8th and 10th Grade. Journal of School Health, 77(1), 29-35.

Henry, K. L., Thornberry, T. P., \& Huizinga, D. H. (2009). A discrete-time survival analysis of the relationship between truancy and the onset of marijuana use. Journal of Studies on Alcohol \& Drugs, 70(1), 5-15.

Henry, K. (2010). Skipping school and using drugs: A brief report. Drugs: Education, Prevention \& Policy, 17(5), 650-657.

Henry, K. L., \& Thornberry, T. P. (2010). Truancy and escalation of substance use during adolescence. Journal of Studies on Alcohol \& Drugs, 71(1), 115-124.

International Association of Truancy and Dropout Prevention (IATDP) (n.d). Mission statement and goal. Retrieved from http://www.iatdp.org/mission.php.

Joftus, S., \& Maddox-Dolan, B. (2003). Left out and left behind: NCLB and the American high school. Washington, DC: Alliance for Excellence in Education.

Katz, M. S. (1976). A history of compulsory education laws. Fastback Series, No. 75. Bicentennial Series. Retrieved from http://files.eric.ed.gov.ezproxy.lib.utah.edu/fulltext/ED119389.pdf

Kearney, C. A. (2006). Dealing with school refusal behavior: A primer for family physicians. Journal of Family Practice, 55(8), 685-692.

Kearney, C. A. (2007). Forms and functions of school refusal behavior in youth: an empirical analysis of 
absenteeism severity. Journal of Child Psychology \& Psychiatry, 48(1), 53-61.

Kearney, C. (2008). An interdisciplinary model of school absenteeism in youth to inform professional practice and public policy. Educational Psychology Review, 20(3), 257-282.

Lawrence, S. A., Lawther, W., Jennison, V., \& Hightower, P. (2011). An evaluation of the early truancy intervention (ETI) program. School Social Work Journal, 35(2), 57-71.

Lehr, C. A., Sinclair, M. F., \& Christenson, S. L. (2004). Addressing student engagement and truancy prevention during the elementary school years: A replication study of the check \& connect model. Journal of Education for Students Placed at Risk, 9(3), 279-301.

Levin, H.M. (1972). The costs to the nation of inadequate education. In Select Committee on Equal Educational Opportunity United States Senate. The effects of dropping out. Washington, DC: U.S. Government Printing Office.

Maynard, B. R., Salas-Wright, C. P., Vaughn, M. G., \& Peters, K. E. (2012). Who are truant youth? Examining distinctive profiles of truant youth using latent profile analysis. Journal of Youth and Adolescence, 41(12), 1671-1684.

Maynard, BR, McCrea, KT, Pigott, T \& Kelly, MS (2012) b. Indicated truancy interventions: Effects on school attendance among chronic truant students, Campbell Systemic Reviews, 10, doi:10.4073/csr.2012.10.

McCray, E. D. (2006). It's 10 a.m.: Do you know where your children are?. Intervention in School \& Clinic, 42(1), 30-33.

McCluskey, C., Bynum, T. S., \& Patchin, J. W. (2004). Reducing chronic absenteeism: An assessment of an early truancy initiative. Crime \& Delinquency, 50(2), 214-234.

McDonald Brown, C., \& Birrane, K.A. (1994). What’s happening to our children? Maryland Journal, 27(3), 35-39.

McIntyre-Bhatty, K. (2008). Truancy and coercive consent: Is there an alternative?. Educational Review, 60(4), 375-390.

McNeal Jr., R. B. (1999). Parental involvement as social capital: Differential effectiveness on science 
achievement, truancy, and dropping out. Social Forces, 78(1), 117-145.

Mogulescu, S., \& Segal, H. J. (2002). Approaches to truancy prevention. New York: Vera Institute of Justice.

Montecel, M.R., Cortez, J.D., \& Cortez, A. (2004). Dropout-prevention programs:

Right intent, wrong focus, and some suggestions on where to go from here.

Education and Urban Society, 36(2), 169-188.

Mounteney, J. J., Haugland, S. S., \& Skutle, A. A. (2010). Truancy, alcohol use and alcohol-related problems in secondary school pupils in Norway. Health Education Research, 25(6), 945-954.

Newsome, W., Anderson-Butcher, D., Fink, J., Hall, L., \& Huffer, J. (2008). The impact of school social work services on student absenteeism and risk factors related to school truancy. School Social Work Journal, 32(2), 21-38.

Office of Juvenile Justice and Delinquency Prevention and Office of Elementary and Secondary Education (1996). Truancy: Creating safe and drug-free schools: An action guide. Washington, DC: US Department of Justice and US Department of Education.

O'Keefe, D., \& Stoll, P. (1994). Truancy in English secondary schools: A report prepared for the DFE. London, DfEE.

Osler, A., Street, C., Lall, M., \& Vincent, K. (2002) Not a problem? Girls and social exclusion. (London, National Children’s Bureau).

Pathammavong, R., Leatherdale, S. T., Ahmed, R., Griffith, J., Nowatzki, J., \& Manske, S. (2011). Examining the link between education related outcomes and student health risk behaviours among Canadian youth: Data from the 2006 National Youth Smoking Survey. Canadian Journal of Education, 34(1), 215-247.

Pritchard, C., \& Williams, R. (2001). A three-year comparative longitudinal study of a school-based social work family service to reduce truancy, delinquency and school exclusions. Journal of Social Welfare \& Family Law, 23(1), 23-43.

Reid, K. (1985). Truancy and school absenteeism. London: Hodder and Stoughton. 
Reid, K. (1999). Truancy and schools. NY: Routledge.

Reid, K. (2003a). A strategic approach to tackling school absenteeism and truancy: The PSCC scheme. Educational Studies (03055698), 29(4), 351-371.

Reid, K. (2003b). Strategic approaches to tackling school absenteeism and truancy: The traffic lights (TL) scheme. Educational Review, 55(3), 305-321.

Reid, K. (2004). A long-term strategic approach to tackling truancy and absenteeism from schools: The SSTG scheme. British Journal of Guidance \& Counselling, 32(1), 57-74.

Reid, K. (2005). The causes, views and traits of school absenteeism and truancy. Research in Education, (74), 59-82.

Reid, K. (2006). The views of education social workers on the management of truancy and other forms of non-attendance. Research in Education, (75), 40-96.

Reid, K. (2007). An evaluation of ofsted reports on LEAs' management of attendance issues. Educational Management Administration \& Leadership, 35(3), 395-413.

Reid, K. (2008). The causes of non-attendance: an empirical study. Educational Review, 60(4), 345-357.

Reid, K. (2010). Finding strategic solutions to reduce truancy. Research in Education, (84), 1-18.

Reid, K. (2014). Managing school attendance: Successful intervention strategies for reducing truancy. Oxon, UK: Routledge.

Reimer, M. S., \& Dimock, K. (2005). Truancy prevention in action: Best practices and model truancy programs. Clemson, SC: Clemson University National Dropout Prevention Center/Network

Rhodes, A. L., \& A. J. Reiss Jr. (1969). Apathy, truancy and delinquency as adaptations to school failure. Social Forces 48 (1), 12-22.

Rhodes, J. F., Thomas, J. M., Lemieux, C. M., Cain, D. S., \& Guin, C. C. (2010). Truancy assessment and service centers (TASC): Engaging elementary school children and their families. School Social Work Journal, 35(1), 83-100.

Rodríguez, L. F., \& Conchas, G. Q. (2009). Preventing truancy and dropout among urban middle school 
youth: Understanding community-based action from the student's perspective. Education \& Urban Society, 41(2), 216-247.

Sinha, J. (2007). Youth at risk for truancy detour into a faith-based education program: Their perceptions of the program and its impact. Research on Social Work Practice, 17(2), 246-257.

Southwell, N. (2006). Truants on truancy - a badness or a valuable indicator of unmet special educational needs? British Journal of Special Education, 33(2), 91-97.

Spencer, A. M. (2009). School attendance patterns, unmet educational needs, and truancy: A chronological perspective. Remedial \& Special Education, 30(5), 309-319.

Texas Education Agency (2011). School finance 101: Funding of Texas public schools. Retrieved from http://www.hamlin.esc14.net/users/0001/docs/School_Finance_101_01142011.pdf

Toby, J. (1957). Social disorganization and stake in conformity. Journal of Crime Law \& Criminology, 48, 12-17.

Ventura, H. E., \& Miller, J. (2005). Finding hidden value through mixed-methodology: Lessons from the discovery program's holistic approach to truancy abatement. American Journal of Criminal Justice, 30(1), 99-120.

Walls, C., \& ERIC Clearinghouse on Urban Education, N. Y. (2003). New approaches to truancy prevention in urban schools. ERIC Digest.

Wardhaugh, J. (1990). Regulating truancy: The role of the education welfare service. Sociological Review, 38(4), 735-764.

Wilson, V., Malcolm, H., Edward, S., \& Davidson, J. (2008). 'Bunking off': the impact of truancy on pupils and teachers. British Educational Research Journal, 34(1), 1-17.

Wilson, J.Q., \& Loury, G.C. (Eds.) (1987). Families, schools, and delinquency prevention. New York: Springer-Verlag.

Zhang, D., Katsiyannis, A., Barrett, D. E., \& Willson, V. (2007). Truancy offenders in the juvenile justice system: Examinations of first and second referrals. Remedial and Special Education, 28(4), 244256. 
Zhang, D., Willson, V., Katsiyannis, A., Barrett, D., Song, J., \& Jiun-Yu, W. (2010). Truancy offenders in the juvenile justice system: A multi-cohort study. Behavioral Disorders, 35(3), 229-242.

Zinth, K. (2005). Truancy and habitual truancy: Examples of state definitions. Retrieved from: ECS State Policy Database: http://www.ecs.org/ecs/ecscat.nsf/WebTopicView?OpenView\&RestrictToCategory=Attendance-Truancy 


\section{Appendix 1 - Definitions around the US}

\begin{tabular}{|c|c|c|}
\hline State & Definition of Truancy & Definition of Habitual Truancy \\
\hline Arizona & $\begin{array}{l}\text { Truancies are unexcused absences for at least one } \\
\text { class period during the school day (ARIZ. REV. STAT. } \\
\S 15-803 \text { ). }\end{array}$ & $\begin{array}{l}\text { Habitually truant students are truant for at least five school } \\
\text { days within a school year (ARIz. REV. STAT. § 15-803). }\end{array}$ \\
\hline California & $\begin{array}{l}\text { Any pupil subject to compulsory full-time education } \\
\text { or to compulsory continuation education who is } \\
\text { absent from school without valid excuse three full } \\
\text { days in one school year or tardy or absent for more } \\
\text { than any } 30 \text {-minute period during the school day } \\
\text { without a valid excuse on three occasions in one } \\
\text { school year, or any combination thereof, is a truant } \\
\text { and shall be reported to the attendance supervisor or } \\
\text { to the superintendent of the school district (CAL. } \\
\text { EDUC. CODE § 48260). } \\
\text { Any pupil who has once been reported as a truant and } \\
\text { who is again absent from school without valid excuse } \\
\text { one or more days, or tardy on one or more days, shall } \\
\text { again be reported as a truant to the attendance } \\
\text { supervisor or the superintendent of the district (CAL. } \\
\text { EDUC. CODE § 48261). }\end{array}$ & $\begin{array}{l}\text { A student is deemed a habitual truant if the student has been } \\
\text { reported as a truant three or more times in one school year. } \\
\text { No student will be deemed an habitual truant unless an } \\
\text { appropriate district officer or employee has made a } \\
\text { conscientious effort to hold at least one conference with a } \\
\text { parent or guardian of the pupil and the pupil himself, after } \\
\text { the filing of either of the reports required by CAL. EDUC. } \\
\text { CODE § } 48260 \text { or CAL. EDUC. CODE § } 48261 \text { (CAL. EDUC. } \\
\text { CODE } § 48262 \text { ). }\end{array}$ \\
\hline Colorado & & $\begin{array}{l}\text { A student between seven and } 16 \text { years old having four } \\
\text { unexcused absences from public school in any one month } \\
\text { or } 10 \text { unexcused absences from public school during any } \\
\text { school year is habitually truant. Absences due to } \\
\text { suspension or expulsion are considered excused (COLO. } \\
\text { REV. STAT. § 22-33-107). }\end{array}$ \\
\hline Connecticut & $\begin{array}{l}\text { Truants are children age five to } 18 \text {, enrolled in a } \\
\text { public or private school with four unexcused absences } \\
\text { from school in any month or } 10 \text { unexcused absences } \\
\text { from school in any school year (CONN. GEN. STAT. § } \\
\text { 10-198A). }\end{array}$ & $\begin{array}{l}\text { Habitual truants are children age five to 18, enrolled in } \\
\text { public or private schools, with } 20 \text { unexcused absences } \\
\text { within a school year (CONN. GEN. STAT. § 10-200). }\end{array}$ \\
\hline Delaware & $\begin{array}{l}\text { Truant means a student who has been absent from } \\
\text { school without valid excuse for more than three } \\
\text { school days during a school year (DEL. ST. TI. 14, § } \\
\text { 2721). }\end{array}$ & \\
\hline Florida & & $\begin{array}{l}\text { A habitual truant is a student who has } 15 \text { unexcused } \\
\text { absences within } 90 \text { calendar days with or without the } \\
\text { knowledge or consent of the student's parent and is subject } \\
\text { to compulsory school attendance (FLA. REV. STAT. § } \\
\text { 1003.01). }\end{array}$ \\
\hline Idaho & & $\begin{array}{l}\text { An habitual truant is a student who - in the judgment of the } \\
\text { board of trustees - has repeatedly violated the attendance } \\
\text { regulations established by the board, or } \\
\text { any child whose parents or guardians have failed or refused } \\
\text { to cause the child to comply with the state's compulsory } \\
\text { attendance law (IDAHO CODE } § 33-206 \text { ). }\end{array}$ \\
\hline Illinois & $\begin{array}{l}\text { A truant is a child subject to compulsory school } \\
\text { attendance and who is absent without valid cause for a } \\
\text { school day or portion thereof (ILL. REV. STAT. CH. } \\
\text { 105, PARA. 5/262A). }\end{array}$ & $\begin{array}{l}\text { A child subject to compulsory school attendance and who is } \\
\text { absent without a valid excuse from school for } 10 \% \text { or more } \\
\text { of the previous } 180 \text { regular attendance days is a chronic or } \\
\text { habitual truant (ILL. REV. STAT. CH. 105, PARA. 5/262A). }\end{array}$ \\
\hline Kentucky & $\begin{array}{l}\text { Any student who has been absent from school without } \\
\text { valid excuse for three or more days, or tardy without }\end{array}$ & $\begin{array}{l}\text { Any child who has been reported as a truant two or more } \\
\text { times is a habitual truant (KY. REV. STAT. ANN. § 159.150). }\end{array}$ \\
\hline
\end{tabular}




\begin{tabular}{|c|c|c|}
\hline State & Definition of Truancy & Definition of Habitual Truancy \\
\hline & $\begin{array}{l}\text { valid excuse on three or more days, is a truant. Being } \\
\text { absent for less than half of a school day is regarded as } \\
\text { being tardy (KY. REV. STAT. ANN. § 159.150). }\end{array}$ & $\begin{array}{l}\text { Any child who has been found by the juvenile court to have } \\
\text { been reported as a truant two or more times during a one- } \\
\text { year period is a habitual truant (KY. REV. STAT. ANN. § } \\
600.020 \text { ). } \\
\text { Per annotations: "While 'habitual truant' is defined } \\
\text { differently in KY. REV. STAT. ANN. § } 159.150 \text { and KY. REV. } \\
\text { STAT. ANN. § 600.020, the statutes may be reconciled in } \\
\text { their application by district courts and pupil personnel } \\
\text { directors." }\end{array}$ \\
\hline Louisiana & & $\begin{array}{l}\text { A student shall be considered habitually absent or } \\
\text { habitually tardy after (1) all reasonable efforts by the } \\
\text { principal and the teacher have failed to correct the condition } \\
\text { after the fifth unexcused absence or fifth unexcused tardy } \\
\text { within any month or (2) if a pattern of five absences a } \\
\text { month is established (LA. REV. STAT. ANN. § 17:233). }\end{array}$ \\
\hline Maine & $\begin{array}{l}\text { A person required to attend school or alternative } \\
\text { instruction under Maine’s compulsory school } \\
\text { attendance law is truant when an absence of a half day } \\
\text { is not excused (ME. REV. STAT. ANN TIT. 20-A, 3272). }\end{array}$ & $\begin{array}{l}\text { A person is habitually truant if they are required to attend } \\
\text { school or alternative instruction and have attained the } \\
\text { equivalent of } 10 \text { full days of unexcused absences or seven } \\
\text { consecutive school days of unexcused absences during a } \\
\text { school year (ME. REV. STAT. ANN TIT. 20-A, 3272). }\end{array}$ \\
\hline Minnesota & & $\begin{array}{l}\text { An habitual truant is a child under the age of } 16 \text { years who } \\
\text { is absent from school without lawful excuse for seven } \\
\text { school days - if the child is in elementary school - or for } \\
\text { one or more class periods on seven school days if the child } \\
\text { is in middle, junior high or high school. A child who is } 16 \\
\text { or } 17 \text { years of age who is absent from school without } \\
\text { excuse for one or more class periods on seven school days } \\
\text { and who has not lawfully withdrawn from school is an } \\
\text { habitual truant (MINN. REV. STAT. § 260C.007). }\end{array}$ \\
\hline Nevada & $\begin{array}{l}\text { A pupil who has one or more unapproved absences } \\
\text { from school is considered truant (NEV. REV. STAT. } \\
\text { ANN. § 392. 130). }\end{array}$ & $\begin{array}{l}\text { Any child who has been declared truant three or more times } \\
\text { within one school year will be declared a habitual truant } \\
\text { (NEV. REV. STAT. ANN. § 392.140). }\end{array}$ \\
\hline New Mexico & $\begin{array}{l}\text { Truant means a student who has accumulated five } \\
\text { unexcused absences within any 20-day period (N.M. } \\
\text { STAT. ANN § 22-12-9). }\end{array}$ & $\begin{array}{l}\text { A student who has accumulated the equivalent of } 10 \text { or } \\
\text { more unexcused absences within a school year is a habitual } \\
\text { truant (N.M. STAT. ANN § 22-12-9). }\end{array}$ \\
\hline Pennsylvania & & $\begin{array}{l}\text { Habitually truant means absence for more than three school } \\
\text { days or its equivalent following the first notice of truancy } \\
\text { given under PA. STAT. ANN. TIT. 24, § 13-1354 (PA. STAT. } \\
\text { ANN. TIT. 24, § 13-1333). }\end{array}$ \\
\hline Texas & & $\begin{array}{l}\text { A student commits an offense if he is required to attend } \\
\text { school under Texas' compulsory school attendance law and } \\
\text { fails to attend school on } 10 \text { or more days or parts of days } \\
\text { within a six-month period in the same school year or on } \\
\text { three or more days or parts of days within a four-week } \\
\text { period (TEX. EDUC. CODE ANN. § 25.094). }\end{array}$ \\
\hline Utah & $\begin{array}{l}\text { Any school-age minor who is subject to the state's } \\
\text { compulsory education law, and who is absent from } \\
\text { school without a legitimate or valid excuse, is truant } \\
\text { (UTAH CODE ANN. § 53A-11-101). }\end{array}$ & $\begin{array}{l}\text { Any school-age minor who has received more than two } \\
\text { truancy citations within one school year from the school in } \\
\text { which they are or should be enrolled and eight absences } \\
\text { without a legitimate or valid excuse or who, in defiance of } \\
\text { efforts on the part of school authorities to resolve a student's } \\
\text { attendance problem, refuses to regularly attend school or }\end{array}$ \\
\hline
\end{tabular}




\begin{tabular}{|c|c|c|}
\hline State & Definition of Truancy & Definition of Habitual Truancy \\
\hline & & $\begin{array}{l}\text { any scheduled period of the school day is an habitual truant } \\
\text { (UTAH CODE ANN. § 53A-11-101). }\end{array}$ \\
\hline Wisconsin & $\begin{array}{l}\text { Truancy means any absence of part or all of one or } \\
\text { more days from school during which the school } \\
\text { attendance officer, principal or teacher has not been } \\
\text { notified of the legal cause of the absence by the } \\
\text { student's parent or guardian. It also means } \\
\text { intermittent attendance carried on for the purpose of } \\
\text { defeating the intent of Wisconsin's compulsory school } \\
\text { attendance law (WIS. REV. STAT. § 118.16). }\end{array}$ & $\begin{array}{l}\text { A student who is absent from school without an acceptable } \\
\text { excuse for part or all of five or more school days during a } \\
\text { school semester is considered habitually truant (WIS. REV. } \\
\text { STAT. § 118.16). }\end{array}$ \\
\hline Wyoming & $\begin{array}{l}\text { An unexcused absence is the absence - as defined in } \\
\text { the policies of the local board of trustees - of any } \\
\text { child required to attend school when such absence is } \\
\text { not excused to the satisfaction of the board of trustees } \\
\text { by the parent or guardian (WYO. STAT. ANN. § 21-4- } \\
\text { 101). }\end{array}$ & $\begin{array}{l}\text { Any child with five or more unexcused absences in any one } \\
\text { school year is a habitual truant (WYO. STAT. ANN. § 21-4- } \\
\text { 101). }\end{array}$ \\
\hline
\end{tabular}

Territory

Guam
Definition of Truancy

Truant means a student found to be absent from school without a reasonable and bona fide excuse from a parent (GUAM CODE ANN. § 6401).
Definition of Habitual Truancy

A student that has incurred 12 or more unexcused absences in a school year, and is of compulsory attendance age, is a habitual truant (GUAM CODE ANN. § 6402).

Resources:

ECS State Policy Database:

http://www.ecs.org/ecs/ecscat.nsf/WebTopicView?OpenView\&RestrictToCategory=Attendance--Truancy

Kyle Zinth, (2005). researcher in the ECS Information Clearinghouse, updated this report. 


\section{Appendix 2 -Definitions of Chronic Truancy in One Midwestern State}

\begin{tabular}{|c|c|}
\hline 1. & Missing school for a reason that is not state approved \\
\hline 2. & over 16 days \\
\hline 3. & parents unaware absence \\
\hline 4. & $\begin{array}{l}\text { A student absent } 7 \text { or more times within the course of the } \\
\text { school year }\end{array}$ \\
\hline 5. & $\begin{array}{l}\text { The act of unauthorized absence from school or class for any } \\
\text { period of time or leaving school proper }\end{array}$ \\
\hline 6. & $10+$ \\
\hline 7. & $\begin{array}{l}3 \text { or more truancies (absent from school without parental } \\
\text { authorization) }\end{array}$ \\
\hline 8. & Multiple unverified absences \\
\hline 9. & 3 or more unexcused absences per semester \\
\hline 10. & 2 or more truancies \\
\hline 11. & 10 absences \\
\hline 12. & 2 or more \\
\hline 13. & repeated absence w/o parent notification to the school \\
\hline 14. & $\begin{array}{l}\text { Truancy is the failure to report to assigned classes or } \\
\text { absences that occur without the knowledge or }\end{array}$ \\
\hline 15. & 3 or more consecutive days absent without notification \\
\hline 16. & $\begin{array}{l}4 \text { truancies (12 unexcused absences or any truancy event } \\
\text { absent without parent knowledge that would e }\end{array}$ \\
\hline 17. & after 15 absences \\
\hline 18. & missing more than 5 days unexcused \\
\hline 19. & 3 truancy incidents \\
\hline 20. & $\begin{array}{l}\text { On several or more occasions being willfully out of school } \\
\text { without the knowledge and/or the approval }\end{array}$ \\
\hline 21. & 10 or more unexcused absences \\
\hline 22. & no defined "habitual" truancy \\
\hline 23. & 10-15 unexcused absences \\
\hline 24. & 3 days truant \\
\hline 25. & More than ten days \\
\hline 26. & 12 or more absences \\
\hline 27. & A student who is truant three times during any semester. \\
\hline 28. & 8 unexcused days of absence \\
\hline 29. & 6 or more days \\
\hline 30. & 3 or more unexcused absences in a row \\
\hline 31. & 5 tardies in a trimester \\
\hline & $\begin{array}{l}\text { Willful refusal to attend school in defiance of parental } \\
\text { authority. }\end{array}$ \\
\hline 33. & unexcused /unreported absence on a "regular" basis \\
\hline 34. & none \\
\hline 35. & same as state's \\
\hline 36. & three reports unofficially ( not stated in handbook) \\
\hline 37. & The same as the state of Indiana \\
\hline & $\begin{array}{l}\text { Absent without permission and notification to proper school } \\
\text { authorities. }\end{array}$ \\
\hline 39. & More than 8 unexcused absences/semester \\
\hline & Missing more than 5 days each six weeks \\
\hline & Absent with 3 or more unexcused absences \\
\hline & 10 or more days without a Dr.'s note \\
\hline & 3 or more unexcused absences \\
\hline 44. & ten or more unexcused absences \\
\hline
\end{tabular}

45. we do not have a specific definition

46. 2 or more unexcused absences in a row

47. 9 unexcused absences

48. Child being absent and neither the parent of school is aware of, or the reason for the absence.

49. 15 absences

50. Any unexcused absence

51. absent for more than 10 days without an excuse

52. absence without just cause

53. third truancy

54. continuing to miss school after repeated warnings

55. More than 10 Absences

56. 4 days of an absence without parental contact.

57. an absence that is not excused and without parental knowledge

58. 3 separate truancy offenses

59. 5 days or more

60. Two or more

61. 10 or more

62. unverified absence or being somewhere other than directed by school personnel

63. Students may not miss more than 10 unexcused days of school.

64. 10 days

65. 12 or more absences without a medical

66. We do not really have a definition, but it would be a student who repeatedly misses school so that $l$

67. Willfully refuses to attend in defiance of parent authority, having 3 incidents of such

68. a student who has more than five unexcused absences in a semester

69. more than 11

70. 3 unexcused absences as determined by the admin

71. more than three times

72. more than two truancy infractions

73. 3 or more misses without notification

74. more than 10 absences of concern

75. 2nd incident of unexcused absence

76. 13 unexcused absences in one year

77. three or more truancies

78. "a student who is chronically absent by having unexcused absences from school for more than ten (10)

79. more than 10 days missed

80. Habitual truancy designation will be applied to any student who is at least 13 years of age but less

81. no parent contact and missing 5+ days

82. A student who is truant 3 or more times

83. over 20 days

84. 10 or more days in a semester

85. 2 or more Undocumented absences

86. no clear definition 
Appendix 3 - Verbatim Focus Group Quotes

\begin{tabular}{|c|c|}
\hline Respondents & Data -- Verbatim Quotes \\
\hline (Person 1) & $\begin{array}{l}\text { My thoughts are; I agree it would be remarkable if we could come to a consensus as an } \\
\text { organization. We all agree that the definition of truancy is very important. I think a national } \\
\text { "Drop out age" would be tremendous! I think we may want to remember the reason for trying } \\
\text { not being so specific is because of the various definitions from state to state. }\end{array}$ \\
\hline (Person 2) & $\begin{array}{l}\text { I am new also. I work in two states as far as Truancy, in Mo. and in KS. But in Ks. St law is 3, } \\
\text { 5, and } 7 . \\
\text { K.S.A. } 72-1113 \text { A student is truant when he she is inexcusably absent from school a significant } \\
\text { part of the school day. } 3 \text { consecutive days-5 days in a school semester-7 days in a school year. } \\
\text { I work as a Drop Out Specialist looking for students who have dropped out. I go look for them } \\
\text { and try to get them back in (enrolled) and when I do I hit a barrier. What I don't understand in } \\
\text { our district is that you can "drop out" without parental permission. But then we have kids who } \\
\text { want to come back to school who let's say parents can't get off work, or even worse, don't care, } \\
\text { the student can't re-enroll without a parent. I'm talking high school age. } \\
\text { We have kids who don't live with their parents, but can't re enroll without a parent, silly!!!!! } \\
\text { I slid off track here, but it should be 18. That way if the student decides to drop out, they can re- } \\
\text { enroll if they want with or w/o a parent. } \\
\text { Mandatory school age is -every child who is enrolled and or } 7 \text { to } 18 \text { years of age. Significant } \\
\text { part of the day is= one third of the day }\end{array}$ \\
\hline (Person 3) & $\begin{array}{l}\text { There also is the issue of those students that never enroll. Technically they aren't absent because } \\
\text { of non-enrollment. Just a thought to add to the definition. Thanks }\end{array}$ \\
\hline (Person 4) & $\begin{array}{l}\text { The definition of truancy is very important. However, I would also like a national "Drop out } \\
\text { age". As an International organization, we may need to ensure that the age is the same from } \\
\text { state to state. }\end{array}$ \\
\hline (Person 5) & $\begin{array}{l}\text { Texas statutes actually address students who are of compulsory attendance age but not enrolled } \\
\text { in school and who are known to live within district boundaries. The problem with those students } \\
\text { is that we rarely become aware of them unless a neighbor or concerned citizen reports them for } \\
\text { being outside during the school day. In our district, our attendance administrators make a home } \\
\text { visit and are generally told the student is being home school. In Texas, we then have no further } \\
\text { educational jurisdiction over the student. } \\
\text { Here's the problem I have with using the word "excused" or "excusable" in the definition of } \\
\text { truancy: parents will always argue that any time they produce a note with a reason for their } \\
\text { student's absence it is/should be excused. We must, therefore, further define what we mean by } \\
\text { "excused" or "excusable" in order to more clearly and comprehensively define truancy. }\end{array}$ \\
\hline (Person 6) & $\begin{array}{l}\text { Works for me. I would just replace child with student so it fits all grade levels. I know how } \\
\text { folks in upper grades don't like being thought of as children. } \\
\text { "Truancy is the act of a student missing any part or all of the school day without a legitimate, } \\
\text { documented excuse or reason." }\end{array}$ \\
\hline (Person 7) & $\begin{array}{l}\text { I'm new to the group but wanted to throw out our definition of truancy. Our county has } \\
\text { expanded the scope to include nonattendance. We did this as it was discovered that MANY } \\
\text { students were missing school with multiple excused absences. We redefined our language as } \\
\text { "nonattendance". The results were similar as those who were unlawful; missed opportunities for } \\
\text { learning. } \\
\text { Definition of truancy/nonattendance: }\end{array}$ \\
\hline
\end{tabular}




\begin{tabular}{|c|c|}
\hline & $\begin{array}{l}\text { When a child misses school or class without an excuse from his or her parent/guardian, leaves } \\
\text { school without permission of the teacher or principal, or is consistently late for school. } \\
\text { I would also add that the word "truant" itself tends to have a connotation referring to kids that } \\
\text { are "delinquent". In our schools officials have a hard time with calling elementary age students } \\
\text { "truants". This is why we went toward nonattendance. }\end{array}$ \\
\hline (Person 8) & $\begin{array}{l}\text { "Truancy is the act of a school aged student being absent without any excusable reason from } \\
\text { any part of a required school day." } \\
\text { "Truancy is the act of missing any part of school without permission" } \\
\text { "Truancy is the act of a school aged student being absent without any excusable reason from } \\
\text { any part of a required school day." }\end{array}$ \\
\hline $\begin{array}{l}\text { (Group of } 8 \\
\text { Teachers) } \\
\end{array}$ & "Truancy is the act of missing any part of school without permission." \\
\hline (Person 9) & $\begin{array}{l}\text { I would prefer to use non-attendance and excessive absenteeism as opposed to truant as well. } \\
\text { For now in terms of excusable and inexcusable, we need to look towards our own State laws to } \\
\text { guide us on that. Maybe that segment should be included "legitimately excused per State law, } \\
\text { city ordinance" whatever you are adhering to. }\end{array}$ \\
\hline
\end{tabular}

